\title{
Perspective of CIGS-BIPV's Product Competitiveness in China
}

\author{
Hui Kong, ${ }^{1,2,3}$ Zhufeng Yu, ${ }^{1}$ Jun Zhang, ${ }^{1}$ Yijie Han, ${ }^{1}$ Lin $W u,{ }^{1}$ Hongsheng Wang $\mathbb{D},{ }^{4}$ \\ and Jian Wang ${ }^{5}$ \\ ${ }^{1}$ China Energy Technology \& Economics Research Institute, Research Building 1, Research Garden of Shenhua Innovation Base, \\ Future Science Park, Changping District, Beijing 102211, China \\ ${ }^{2}$ State Key Laboratory of Power System, Department of Thermal Engineering, Tsinghua-BP Clean Energy Center, \\ Tsinghua University, Beijing 100084, China \\ ${ }^{3}$ School of Mechanical Engineering, Beijing Institute of Technology, Beijing 100081, China \\ ${ }^{4}$ MOE Key Laboratory of Hydrodynamic Machinery Transients (Wuhan University), Ministry of Education, School of Power and \\ Mechanical Engineering, Wuhan University, Wuhan, Hubei 430072, China \\ ${ }^{5}$ Department of Chemistry, Seoul National University, Seoul, Republic of Korea
}

Correspondence should be addressed to Hongsheng Wang; wanghongsheng@whu.edu.cn and Jian Wang; jwangbx@connect.ust.hk

Received 14 February 2020; Revised 28 April 2020; Accepted 11 July 2020; Published 11 August 2020

Academic Editor: Tanka R. Rana

Copyright (c) 2020 Hui Kong et al. This is an open access article distributed under the Creative Commons Attribution License, which permits unrestricted use, distribution, and reproduction in any medium, provided the original work is properly cited.

Copper indium gallium selenide (CIGS) thin-film battery has high photoelectric conversion efficiency, better spectral dispersion ability, and weak light-adsorption characteristics, as well as shape and size flexibility. CIGS-BIPV (building integrated photovoltaic) has attracted more and more research attention with the advantages of good curvature, form and color diversity, and broad application prospects. This paper uses the classical "Porter's Five Forces Model" to make a preliminary analysis of the competitiveness of CIGS-BIPV products. A more specific competitiveness analysis model is further built with the index modeling method, and the competitiveness of CIGS-BIPV products is thoroughly analyzed from qualitative and quantitative perspectives. Six primary research indicators are used, i.e., safety index, building aesthetics index, economic index, energy-saving and environmental protection index, innovation index, and sales force index. The weight analysis of index modeling shows that compared with a glass curtain wall, exterior stone, and silica-based BIPV, CIGS-BIPV is characterized by high product competitiveness, acceptable cost, attractive appearance, environmental benignity, high technical quality, and certain economic benefits. The product competitiveness of CIGS-BIPV could be further enhanced through the construction and promotion of sales channels.

\section{Introduction}

Due to the increasing environmental protection pressure and energy deficiency, the development and utilization of solar energy and other renewable energy forms are now becoming an important part of national sustainable development strategies $[1,2]$. Solar energy is one of the most abundant energy resources among current renewable energy options and could meet the energy consumption demand of human beings in the long future [3]. Photothermal conversion [4-6], photoelectric conversion [7], and photochemical conversion [8] are the three main ways of solar energy utilization $[9,10]$. According to the International Energy
Agency, solar photovoltaics will drive strong rebound from 2019 to 2024 [11] (shown in Figure 1), and its proportion in global energy will reach about 25\% in 2050 and $64 \%$ in 2100 , respectively, implying a leading role of it in the energy structure $[12,13]$. According to the "13th FiveYear Plan" for power development issued by the National Energy Administration of China, solar power generation capacity will be increased by more than 68 million kilowatts within 2016 and 2020. In 2020, the national installed capacity of solar power will reach 110 million kilowatts, including more than 60 million kilowatts of distributed photovoltaics and 5 million kilowatts of solar thermal power [14]. 


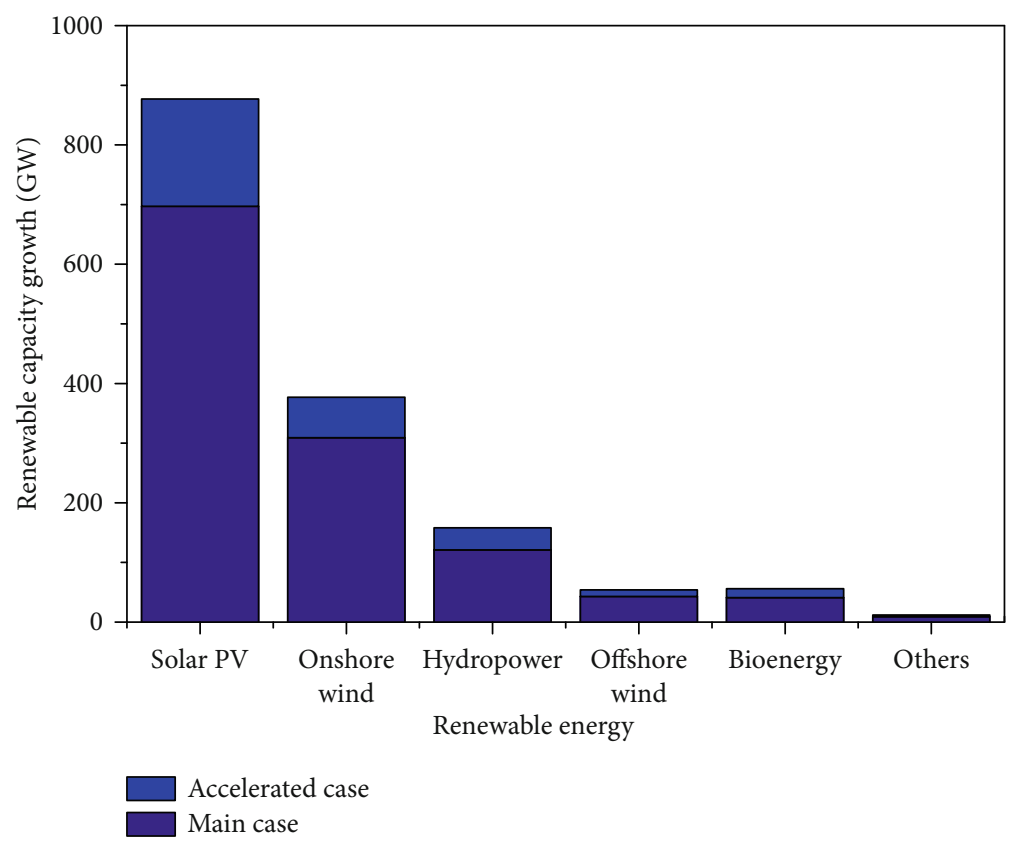

Figure 1: Renewable capacity growth between 2019 and 2024, from IEA [11].

CIGS (copper, indium, gallium, and selenium) thin-film solar cell has the advantages of strong light absorption ability, high electricity-generation capacity and stability, low production cost, and short energy recovery period, which lead to its rapid development among various thin-film solar cell production technologies [15-18]. Traditional thin-film solar cells are mainly installed on buildings to form photovoltaic power generation systems, while in the CIGS-BIPV (copper, indium, gallium, and selenium-building integrated photovoltaic) system, CIGS thin-film solar cells and buildings are designed, constructed, and installed simultaneously with an optimal integration [19]. As a part of building external structure, CIGS-BIPV not only generates electricity and functions as building component and material but also improves the appearance of buildings.

From the perspective of the life cycle, CIGS-BIPV is currently still in the lead-in stage. A comprehensive analysis of the competitiveness of CIGS-BIPV products is crucial to the market development and capital investment for the future research direction. However, to the best of our understanding, there are few research literatures on the competitiveness of CIGS-BIPV products. In order to eliminate this gap, in this paper, "Porter's Five Forces Model" $[20,21]$ is for the first time used to perform a preliminary analysis on CIGS-BIPV product competency, the method of which has been widely applied to analyze the industry competition of different markets, such as the competition of shale gas [22], biomass power generation [23], medical education [24], and electronic virtual [25]. In order to compensate the limitations of the "Porter's Five Forces Model," the CIGS-BIPV product's competitiveness is further competed qualitatively and quantitatively by means of index modeling, where safety index, i.e., architectural aesthetic index, economic index, energy-saving and environmental protection index, innovation index, and sales force index are used. Figure 2 is the main

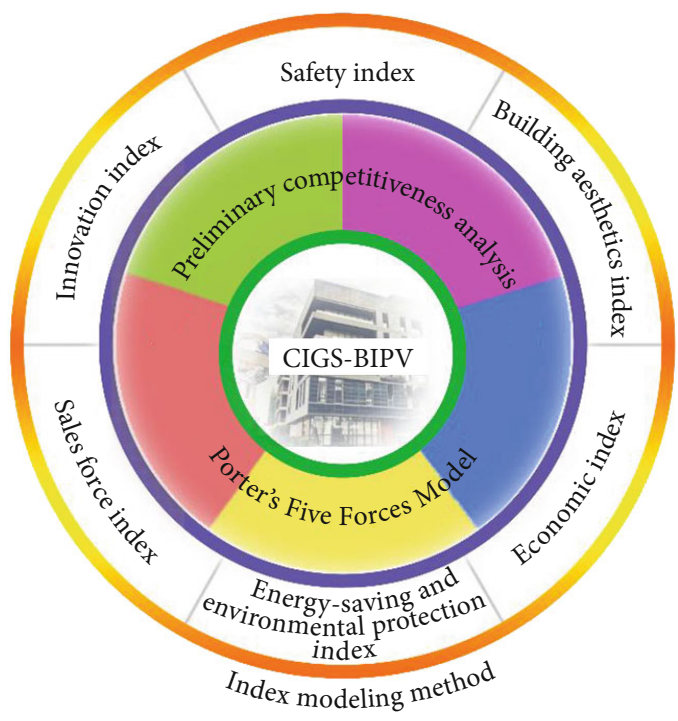

FIgURE 2: Schematic diagram of CIGS-BIPV competitiveness analysis.

schematic diagram of CIGS-BIPV competitiveness analysis. At the end of this paper, through the evaluation and comparison of key strategic factors in the industry, and giving different weights, the "competition situation matrix" is used to analyze the competitiveness of CIGS-BIPV, exterior stone (or hanging stone), silica-based BIPV, and glass curtain wall.

\section{Preliminary Analysis of "Porter's Five Forces Model” for CIGS-BIPV}

For product competitiveness analysis, "Porter's Five Forces Model" is generally used, where "Five Forces" are the competitiveness of existing competitors in the industry, the 
ability of potential competitors to enter, the substitution ability of substitutes, the bargaining power of suppliers, and the bargaining power of buyers [26].

Rivalry among existing competitors is the most competing factor among "Porter's Five Forces Model" for CIGSBIPV product, and the major competitors include silicabased BIPV, other types of thin-film solar cells-BIPV, glass curtain wall, and exterior stone. Profits among different products are mutually related, and the goal is to make their products superior to their competitors.

The threat of new entrants affects the competitiveness of CIGS-BIPV products. In the field of BIPV, CIGS-BIPV itself is a new entrant, bringing new production capacity and new resources to the industry. In the meantime, the major obstacle of entering the market for another new silica-based BIPV primarily includes product differences, capital demand, conversion cost, development of sales channel, and government behavior and policy. The relationship among potential profit, cost of expenditure, and risks of products have to be fully considered by the newcomers of the BIPV market.

CIGS-BIPV market space can be threatened by substitutes. Current substitutes of CIGS-BIPV can be silica-based BIPV, CdTe- (cadmium telluride-) BIPV, GaAs- (gallium arsenide-) BIPV in the same industry, or even products like glass curtain wall, exterior stone in different industries. The competency strategies of CIGS-BIPV companies can be influenced by those competencies from substitutes in various forms. The competitive pressure will be higher if the substitutes of CIGS-BIPV have a lower price, better quality, and lower user costs. The competitive pressure intensity of those substitutes can be evaluated by sales growth, production capacity, and profit expansion status. Moreover, security and innovativeness also need to be fully considered.

Production expenditure of CIGS-BIPV is also impacted by the bargaining power of suppliers. Quite few suppliers exist for critical components and technologies in thin-film solar cells of CIGS-BIPV, which is an oligopoly market. Core technologies are held by some companies with plenty of patents. The profit is also shared by downstream suppliers, which is also one of the major causes of the high expenditure of CIGS thin-film solar cells. Although China has invested a lot of funds to acquire foreign-funded enterprises, how to fully master the original technology and bring forth new products to realize the localization of products is crucial. In addition, some noncore parts of CIGS-BIPV have plenty of suppliers with bad bargaining power.

The profit of CIGS-BIPV can also be impacted by customer's bargaining power. The profitability of the product is influenced by BIPV customers' bargain and the requirement to provide better product or service quality. At present, CIGS-BIPV is still in the lead-in period of its life cycle, and its cost is high. The buyers are mainly stateowned enterprises and private enterprises with betteroperating conditions. Essentially, CIGS-BIPV is a giant monopoly field with low bargaining power. On the other hand, CIGS-BIPV is too expensive for private customers and ordinary families, who have other purchase options like glass curtain wall and exterior stone. Governmental policy support, the establishment of brand value for BIPV, and the essential promotion of sustainable building characteristics are of great importance.

Above all, the competency of CIGS-BIPV in five aspects is initially analyzed using "Porter's Five Forces Model". However, it is worth noting that "Porter's Five Forces Model" has certain limitations, and it is a competitive analysis model based on a relatively fixed industry scale. CIGS-BIPV is in the lead-in period, which requires cooperation from enterprises to obtain more resources and markets. At present, output and application quantities for CIGS-BIPV are increasing rapidly both domestically and internationally. In the meantime, not only competency but also cooperation exists among different BIPV companies.

\section{Index Modeling for the Competency of CIGS- BIPV Product}

CIGS-BIPV products are now gradually recognized and accepted in the market, and the industry has begun to form and grow. At the early stage of the product lifecycle, large efforts have to be made to cultivate markets and improve products, due to the small number of related companies, low market demand, unstable product quality, and slow development. Based on the initial analysis of "Porter's Five Forces Model," an index modeling approach is adopted to further analyze the competency of CIGS-BIPV products. This approach can realize the combination of qualitative and quantitative analyses. The selected parameters are safety index, architectural aesthetics index, economic index, energy-saving and environmental protection index, innovation index, and sales force index.

3.1. Comparative Analysis of Safety Index. First of all, the safety of the glass curtain wall, exterior stone, silica-based BIPV, and CIGS-BIPV is compared and analyzed. The glass curtain wall has the forms of single-layer and multilayer glasses. Glass curtain wall is composed of panel and metal frame with low deformation capacity. When the structure is experiencing lateral displacement under horizontal earthquake or wind load, the impact of excessive lateral displacement in subject structure can only be avoided through the elasticity of connectors, since the panel and metal frame of glass curtain wall cannot withstand such large displacement. A certain amount of gap has to be generated between glass and frame to ensure that glass will not be pressed and broken in case of interlayer displacement.

The exterior stone uses corrosion-resistant bolts and flexible joints to hang granite, artificial marble, and other decorative stones directly on the exterior of the building structure. A certain amount of deflection is allowed under the effect of wind and earthquake loads as parts of the loads can be absorbed to eliminate the crack and fall off. Stone materials will reset with the structure when the wind and earthquake loads disappear. The pressure resistance and shock resistance of the external stone are relatively high. The existence of brittleness, microcracks, internal nonuniform areas, and defects could result in stress concentration, which leads to the low actual strength. 
TABLE 1: Safety index analysis of four products.

\begin{tabular}{|c|c|c|c|c|c|c|c|c|c|}
\hline \multirow{2}{*}{ Safety index } & \multirow{2}{*}{ Weight factor } & \multicolumn{2}{|r|}{ CIGS-BIPV } & \multicolumn{2}{|c|}{ Silica-based BIPV } & \multicolumn{2}{|c|}{ Glass curtain wall } & \multicolumn{2}{|c|}{ Exterior stone } \\
\hline & & Score & Weighted value & Score & Weighted value & Score & Weighted value & Score & Weighted value \\
\hline Strength & 0.5 & 90 & 45 & 90 & 45 & 95 & 47.5 & 84 & 42 \\
\hline Pressure resistance & 0.3 & 90 & 27 & 86 & 25.8 & 95 & 28.5 & 90 & 27 \\
\hline Antiknock characteristic & 0.2 & 90 & 18 & 86 & 17.2 & 95 & 19 & 80 & 16 \\
\hline & 1.00 & & 90 & & 88 & & 95 & & 85 \\
\hline
\end{tabular}

TABle 2: An analysis of the architectural aesthetic indexes of four products.

\begin{tabular}{|c|c|c|c|c|c|c|c|c|c|}
\hline \multirow{2}{*}{$\begin{array}{l}\text { Architectural aesthetic } \\
\text { index }\end{array}$} & \multirow{2}{*}{$\begin{array}{l}\text { Weight } \\
\text { factor }\end{array}$} & \multicolumn{2}{|c|}{ CIGS-BIPV } & \multicolumn{2}{|c|}{ Silica-based BIPV } & \multicolumn{2}{|c|}{ Glass curtain wall } & \multicolumn{2}{|c|}{ Exterior stone } \\
\hline & & Score & $\begin{array}{l}\text { Weighted } \\
\text { value }\end{array}$ & Score & $\begin{array}{l}\text { Weighted } \\
\text { value }\end{array}$ & Score & $\begin{array}{l}\text { Weighted } \\
\text { value }\end{array}$ & Score & $\begin{array}{l}\text { Weighted } \\
\text { value }\end{array}$ \\
\hline Brightness & 0.3 & 90 & 27 & 90 & 27 & 95 & 28.5 & 88 & 26.4 \\
\hline Color diversity & 0.4 & 90 & 36 & 88 & 35.2 & 95 & 38 & 90 & 36 \\
\hline Surface texture & 0.3 & 90 & 27 & 86 & 25.8 & 95 & 28.5 & 92 & 27.6 \\
\hline & 1 & & 90 & & 88 & & 95 & & 90 \\
\hline
\end{tabular}

TABLE 3: An analysis of the economic indexes of four products.

\begin{tabular}{lccccccccc}
\hline \multirow{2}{*}{ Economic index } & \multirow{2}{*}{ Weight factor } & \multicolumn{2}{c}{ CIGS-BIPV } & \multicolumn{2}{c}{ Silica-based BIPV } & \multicolumn{2}{c}{ Glass curtain wall } & \multicolumn{2}{c}{ Exterior stone } \\
& & Score & Weighted value & Score & Weighted value & Score & Weighted value & Score & Weighted value \\
\hline Initial investment & 0.3 & 70 & 21 & 76 & 22.8 & 90 & 27 & 96 & 28.8 \\
Composite cost & 0.3 & 70 & 21 & 80 & 24 & 90 & 27 & 96 & 28.8 \\
Prospective earnings & 0.4 & 83 & 33.2 & 82 & 32.8 & 78 & 31.2 & 80 & 32 \\
& 1 & & 75.2 & & 79.6 & & 85.2 & 89.6 \\
\hline
\end{tabular}

TABLE 4: Analysis of energy-saving and environmental protection indexes of four products.

\begin{tabular}{|c|c|c|c|c|c|c|c|c|c|}
\hline \multirow{2}{*}{$\begin{array}{l}\text { Energy-saving and environmental } \\
\text { protection index }\end{array}$} & \multirow[b]{2}{*}{$\begin{array}{l}\text { Weight } \\
\text { factor }\end{array}$} & \multicolumn{2}{|c|}{ CIGS-BIPV } & \multicolumn{2}{|c|}{ Silica-based BIPV } & \multicolumn{2}{|c|}{ Glass curtain wall } & \multicolumn{2}{|c|}{ Exterior stone } \\
\hline & & Score & $\begin{array}{l}\text { Weighted } \\
\text { value }\end{array}$ & Score & $\begin{array}{l}\text { Weighted } \\
\text { value }\end{array}$ & Score & $\begin{array}{l}\text { Weighted } \\
\text { value }\end{array}$ & Score & $\begin{array}{c}\text { Weighted } \\
\text { value }\end{array}$ \\
\hline Power saving & 0.6 & 96 & 57.6 & 94 & 56.4 & 80 & 48 & 75 & 45 \\
\hline Pollution reduction & 0.2 & 93 & 18.6 & 91 & 18.2 & 80 & 16 & 75 & 15 \\
\hline \multirow[t]{2}{*}{$\mathrm{CO}_{2}$ emission reduction } & 0.2 & 94 & 18.8 & 92 & 18.4 & 80 & 16 & 75 & 15 \\
\hline & 1 & & 95 & & 93 & & 80 & & 75 \\
\hline
\end{tabular}

In theory, the photovoltaic modules of BIPV meet the safety requirements of the designed standard, such as thinfilm solar cell factory design standard (GB51370-2019), and have good temperature and humidity resistance, mechanical strength, and electrical insulation characteristics [27]. Considering the low safety of the surface coating, the surface layer of silica-based materials is usually covered by a glass layer, which is not easy to bend. However, when there is a fire risk, the glass on the surface layer usually becomes fragments, which is a major threat to the safety of firefighters, while the ETFE (ethylene tetrafluoroethylene) or other coatings on the surface layer of CIGS materials could avoid such a problem [28]. Thin-film battery has better compression property, while monocrystalline and polycrystalline silicon batteries will probably deform or even break under snow load, resulting in an unnecessary loss.

In terms of safety, the glass curtain wall shows better reliability than CIGS-BIPV, silica-based BIPV, and exterior stone, shown in Table 1 . This conclusion is obtained primarily based on the strength and shearing resistance of the material itself. In real production and construction, it is necessary to strictly follow the corresponding standards and analyze the plate structure of the construction site. In addition, it is also necessary to figure out whether it is an earthquake-prone area, temperature difference between morning and night, there is a huge wind, heavy rain/snow, or not as well as some other environmental factors. Safety should be the top priority for all the index analysis and actual production. With safety margin reserved, relevant safety protection measures shall be provided according to different characteristics of each product. However, it is worth to mention that the weight factor index and the scores in Table 1 (and Tables 2-6) are chosen from an expert discussion based on 1000 questionnaires in October 2019. They would change according to the technological progress with time, but the calculation method for safety and other index analysis is still applicable. 
TABLE 5: An analysis of the innovation indexes of four products.

\begin{tabular}{|c|c|c|c|c|c|c|c|c|c|}
\hline \multirow[b]{2}{*}{ Innovation index } & \multirow[b]{2}{*}{$\begin{array}{l}\text { Weight } \\
\text { factor }\end{array}$} & \multicolumn{2}{|c|}{ CIGS-BIPV } & \multicolumn{2}{|c|}{ Silica-based BIPV } & \multicolumn{2}{|c|}{ Glass curtain wall } & \multicolumn{2}{|c|}{ Exterior stone } \\
\hline & & Score & $\begin{array}{l}\text { Weighted } \\
\text { value }\end{array}$ & Score & $\begin{array}{l}\text { Weighted } \\
\text { value }\end{array}$ & Score & $\begin{array}{l}\text { Weighted } \\
\text { value }\end{array}$ & Score & $\begin{array}{l}\text { Weighted } \\
\text { value }\end{array}$ \\
\hline High tech content of products & 0.5 & 95 & 47.5 & 93 & 46.5 & 82 & 41 & 77 & 38.5 \\
\hline $\begin{array}{l}\text { Space for technological } \\
\text { progress }\end{array}$ & 0.5 & 95 & 47.5 & 91 & 45.5 & 78 & 39 & 73 & 36.5 \\
\hline & 1 & & 95 & & 92 & & 80 & & 75 \\
\hline
\end{tabular}

TABLE 6: Analysis of sales force index of four products.

\begin{tabular}{|c|c|c|c|c|c|c|c|c|c|}
\hline \multirow[b]{2}{*}{ Sales force index } & \multirow[b]{2}{*}{$\begin{array}{l}\text { Weight } \\
\text { factor }\end{array}$} & \multicolumn{2}{|c|}{ CIGS-BIPV } & \multicolumn{2}{|c|}{ Silica-based BIPV } & \multicolumn{2}{|c|}{ Glass curtain wall } & \multicolumn{2}{|c|}{ Exterior stone } \\
\hline & & Score & $\begin{array}{l}\text { Weighted } \\
\text { value }\end{array}$ & Score & $\begin{array}{l}\text { Weighted } \\
\text { value }\end{array}$ & Score & $\begin{array}{l}\text { Weighted } \\
\text { value }\end{array}$ & Score & $\begin{array}{l}\text { Weighted } \\
\text { value }\end{array}$ \\
\hline Corporate strength & 0.2 & 88 & 17.6 & 87 & 17.4 & 89 & 17.8 & 87 & 17.4 \\
\hline Brand value & 0.2 & 84 & 16.8 & 85 & 17 & 90 & 18 & 90 & 18 \\
\hline Price/performance ratio & 0.25 & 84 & 21 & 82 & 20.5 & 92 & 23 & 90 & 22.5 \\
\hline Customer satisfaction & 0.15 & 78 & 11.7 & 75 & 11.25 & 88 & 13.2 & 87 & 13.05 \\
\hline \multirow[t]{2}{*}{ Sales channel construction } & 0.2 & 65 & 13 & 70 & 14 & 90 & 18 & 96 & 19.2 \\
\hline & 1 & & 80.1 & & 80.15 & & 90 & & 90.15 \\
\hline
\end{tabular}

3.2. Comparative Analysis of Architectural Aesthetic Index. The glass curtain wall endows the building with integrating architectural aesthetics, architectural function, architectural energy-saving, and architectural structure and makes the building display different colors from different angles. The color-adjustable feature of the glass curtain wall panel also meets various user needs. The inner side of the curtain wall's outer glass is coated with colorful metal deposition. From the appearance, the whole exterior wall is like a mirror. Under the reflection of light, the interior space of the building is not exposed to strong light, and the vision is soft.

Generally, the slabs of the exterior stone are processed with the same vein stone. Before installation, they need to be selected and numbered to ensure that the stone texture and direction are correct, and the transition is natural without a color difference. The quality of stone and processing will have an impact on the beauty. Stone color, line, form, owner's requirements, and structural needs such as shape and awning should be considered together with the style of the whole building. The convenience of construction is another concern in the layout. Compared with the visual enjoyment given by the glass curtain wall, the exterior stone is much lower.

The overall product design and visual enjoyment are nonnegligible for the BIPV market. Although silica-based photovoltaic cells occupy a leading position in the market share, there are many places that prefer to adopt thin-film solar cells, since thin-film solar cells have a more flexible design, arbitrarily shape and size, good curvature, and better overall characteristics. In terms of aesthetics requirements, the overall appearance of BIPV components has to be considered to coordinate with the whole building color and structure.

Apart from the attached importance to appearance, CIGS-BIPV can also preserve the functionalities of the build- ing structure. In real applications, bypass diode, main junction box, connectors, and other devices are hidden inside the building curtain wall by BIPV to reach the aesthetic effect. In the meantime, it prevents rain erosion and direct sunlight from affecting the equipment and lines. Production of components with different colors and patterns can be customized for CIGS thin-film solar cells to accommodate different market applications and demands, especially the demand on building aesthetics by architects on colors and specifications. For buildings, light is essential, and the requirements for light and shadow are very high. Double-sided glass components made by a smooth ultrawhite tempered glass are adopted by BIPV buildings, and cell configurations can be adjusted to reach a certain transmittance. The components can be installed on the façade of the building because of the low requirement of CIGS-BIPV for a light angle. The architectural aesthetic index analysis of these four products is shown in Table 2.

3.3. Comparative Analysis of Economic Index. The economy is one of the very important indexes for market competency of products, which primarily includes investment, cost, and profit. Compared with exterior stone and glass curtain wall, silica-based BIPV and CIGS-BIPV have the characteristics of power output, while double-layer and three-layer structures of glass curtain wall have better thermal economy performance than exterior stone. According to the survey of our cooperation and the literature $[29,30]$, the production costs of PV module in China (December 2019) for CIGS thinfilm solar cells, monocrystal silicon solar cells, polycrystalline silicon solar cells, and amorphous solar cells are about 4.006.00 RMB/W, 1.75 RMB/W, 1.58 RMB/W, and 1.65 RMB/W, respectively. Through the comparison on production costs of different solar cell types, the cost of CIGS thin-film solar cell is much higher but within the acceptable range with further 
improvement of the power generation efficiency, which is worth broad promotion and application. The thin-film solar cell does not require affiliated devices like holder, and the maintenance is relatively simple. Compared with crystal solar cells, the thin-film solar cell could save a one-time investment cost and later maintenance cost.

Although the cost for solar cells has decreased tremendously in recent years, the price of BIPV components has not decreased much. CIGS-BIPV and silica-based BIPV are both in the lead-in period of product life with high construction cost, and the current utilization goals are entering middle and high-end construction market. Based on the construction experience of our cooperation building, the average price of some high-end building materials (exterior stone and glass curtain wall) and BIPV (CIGS-BIPV and silica-based BIPV [31]) is about $800-1800 \mathrm{RMB} / \mathrm{m}^{2}$ and above 2500 $\mathrm{RMB} / \mathrm{m}^{2}$, respectively, considering the construction and installation costs. The advantage of BIPV is that it avoids the fuel and power costs in operation, but the final system purchase and installation costs are quite expensive considering the initial investment. The initial cost of traditional energy use is low, but the operation and maintenance costs are high, and the damage to the environment cannot be ignored, such as the burning of coal, which will release a lot of greenhouse gases. Materials for BIPV building are not more expensive than the ones for high-grade building, and the cost is constantly falling through the formation of industrial chain and commercial promotion.

From the perspective of extra power generation, the profits of exterior stone and glass curtain wall are zero. For silica-based BIPV, the power generation is about $155 \mathrm{~W} / \mathrm{m}^{2}$, and the average annual power generation is about $101 \mathrm{kWh} / \mathrm{m}^{2}$ if the power generation period is calculated as 650 hours per year. The annual income per square meter for silica-based BIPV is about 50.5 RMB. For CIGS-BIPV, the power generation per square meter is about $150 \mathrm{~W}$ if 700 power generation hours are taken into account each year. The average annual power generation is about $105 \mathrm{kWh} / \mathrm{m}^{2}$, and the annual benefit per square meter is about $52.5 \mathrm{RMB}$. Here, the photovoltaic electricity price is assumed to be 0.5 $\mathrm{RMB} / \mathrm{kWh}$, although it varies according to the first, second, and third resource zones to which it belongs. In addition, China's National Development and Reform Commission stipulates in [2019] No. 761 that the total power generation subsidy for household distributed photovoltaics is adjusted to $0.18 \mathrm{RMB} / \mathrm{kWh}$ [32]. However, considering the comparison and analysis of economic indicators (initial investment, composite cost, prospective earnings, etc.), the competitiveness of CIGS-BIPV is still weak among these four products, shown in Table 3.

3.4. Comparative Analysis of Energy-Saving and Environmental Protection Index. Green building refers to the building that can save resources (energy, land, water, and material) to the maximum extent in the whole life cycle, protect the environment and reduce pollution, provide people with healthy, comfortable, and efficient use space, and exist in harmony with nature. Extra insulation approach has to be taken for traditional exterior stone, while glass curtain wall, CIGS-BIPV, and silica-based BIPV can adopt double-layer or even three-layer structures, which is helpful for the thermal insulation of buildings and hence reduces the extra demand on fossil fuels. Regarding architectural function, too many supports and crystalline silicon batteries are huge burdens for buildings in the long term, which will cause the consumption of bearing capacity, shorten the service life of buildings, and even bring security risks. On the contrary, a thin-film battery is a piece of lightweight material that can address the above concerns.

CIGS-BIPV shows apparent advantages in energy-saving and environmental protection, and it has a lower environment demand. The BIPV system can be used wherever sunlight exists, and power transmission difficulties in a remote area can be effectively resolved. Energy consumption of a building is recognized as one of the most important energy consumption part in today's society, accounting for about $1 / 3$ of the total energy consumption in China. In particular, the residential area of central heating in northern China only accounts for $10 \%$ of the national urban residential area, but the building energy consumption accounts for $40 \%$. CIGSBIPV could reduce greenhouse gas emissions. Taken the CIGS-BIPV demonstration building in Tonghu town (Guangdong Province, China) as an example, the annual power generation is about $117,000 \mathrm{kWh}$, which will save 36.27 tons of standard coal and eliminate 64.63 tons of carbon dioxide emission annually. About 1,293 tons of carbon dioxide emission can totally be avoided for Tonghu town considering the lifespan of CIGS-BIPV as 20 years. The adoption of distributed electricity generation mode can efficiently avoid large land occupation for power stations and expensive energy storage equipments. In the meantime, cost and energy consumption can be decreased during electricity transmission. More importantly, serious air pollution caused by fossil fuel power generation can be eliminated, which is of great importance to meet the higher environmental protection requirements in the future. CIGS-BIPV shows great competitiveness than silica-based BIPV, glass curtain wall, and exterior stone from the perspective of energy-saving and environmental protection, shown in Table 4.

3.5. Comparative Analysis of Innovation Index. The glass curtain wall of modern high-rise building adopts the hollow structure which is composed of mirror glass and common glass, and the interlayer is filled with dry air or inert gas. Insulating glass has the advantages of sound insulation, heat insulation, frost and moisture proof, as well as wind pressure resistance, etc. The external hanging stone materials are continuously optimized in cutting, fixing, and stability of plates, and the aesthetics are also improved. Compared with a glass curtain wall and traditional exterior stone building, BIPV's main innovation lies in meeting a large part of the building's electricity demand, which is green and energy-saving. The following is a comparative analysis of silica-based BIPV and CIGS-BIPV in terms of innovative index.

CIGS thin-film solar cell is composed of four chemical elements including $\mathrm{Cu}, \mathrm{In}, \mathrm{Ga}$, and Se (direct gap semiconductor). Its light absorption coefficient is up to $\sim 10^{5} \mathrm{~cm}^{-1}$ for high-energy photons $(1.5 \mathrm{eV})$, and battery absorption 


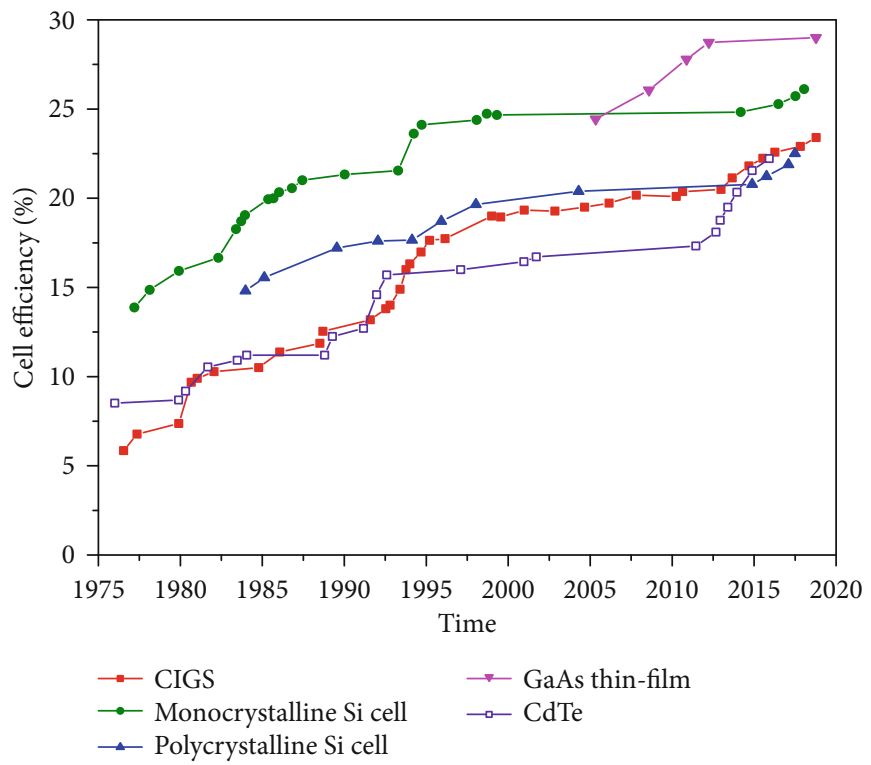

FIgURE 3: The highest confirmed cell efficiencies of typical research cells from 1975 to the present [34].

thickness can be as low as a few micrometers [33]. As a result, the consumption of raw materials for the building of CIGS thin-film solar cells can be dramatically decreased.

In terms of efficiency, based on better spectral dispersion ability, CIGS thin-film solar cell could be as efficient as silicabased photovoltaic components. Single junction cell efficiencies under 1 sun for a range of photovoltaic technologies are shown in Figure 3 [34]. The highest photoelectric conversion efficiency of high-efficiency monocrystalline (single-crystal) silicon solar cell laboratory has reached $27.8 \%$, and that of high-efficiency polycrystalline silicon solar cell laboratory has reached $22.3 \%$ in 2018 [34]. MCT cooperated with the German solar hydrogen energy research institute (ZSW) and reported a laboratory efficiency of $21.7 \%$ for CIGS thin-film solar cell in 2014 [35]. The efficiency has been further improved to $23.4 \%$ by the Institute of Semiconductors, Chinese Academy of Sciences [34] in 2018. The improvement of photoelectric conversion efficiency lays a foundation for the practical and industrial application of solar cells. The conversion efficiency of CIGS thin-film solar cells on flexible substrates has been constantly refreshed, which has a very broad application prospect.

CIGS thin-film solar cell not only shows comparatively high conversion efficiency under direct sunlight but also has good weak light-adsorption characteristics that other solar cells cannot match. The photoelectric conversion efficiency of CIGS thin-film solar cell is much higher than other solar cells even in areas with low intensity of solar radiation. The photoelectric conversion efficiency could be relatively high under any solar radiation intensity, which is also one of the main advantages for CIGS thin-film solar cell to realize the industrialization and commercialization.

In the silica-based BIPV photovoltaic modules, poly(vinyl butyral-co-vinyl alcohol-co-vinyl acetate) (PVB) or poly(ethylene-co-vinyl acetate) (EVA) are primarily utilized by single-crystal silicon or polycrystalline silicon cells to get encapsulated among multilayer toughened glasses [36]. By adjusting the arrangement number and spacing of the battery pieces, the light transmittance of the module can also meet the specific requirements. Some crystalline silicon photovoltaic modules also use color cells. In order to improve the light transmittance of the modules, the number of internal cells is less and the arrangement spacing is larger, so the power generation is naturally smaller. Sputtering technique, large-area deposition, or coevaporation [37] technologies are generally adopted during the manufacture of thin-film BIPV photovoltaic components. Thin-film BIPV photovoltaic modules can be made into flexible photovoltaic modules and have good low light power generation performance and temperature coefficient, which has a relatively ideal application effect in shade resistance. CIGS-BIPV still has strong innovation and technological progress space, and its competitiveness from the perspective of innovation is pretty high, shown in Table 5.

3.6. Comparative Analysis of Sales Force Index. In comparison with exterior stone and glass curtain wall that have matured sales channels, CIGS-BIPV products still have to improve their sales competitiveness. The most basic function of BIPV is for building, and power generation is its auxiliary function. CIGS-BIPV could be more consistent with building intelligence principle, safety and stability principle, and economic suitability than silica-based BIPV. In China, silicabased solar cells are usually produced and sold by small and private companies, while CIGS-BIPV is usually developed, produced, and sold by large state-owned companies and local state-owned companies. For example, Chongqing Shenhua CIGS thin-film solar cell module project enterprise, funded by China Energy Investment Corporation and Shanghai Electric, is providing a strong technical and economic 


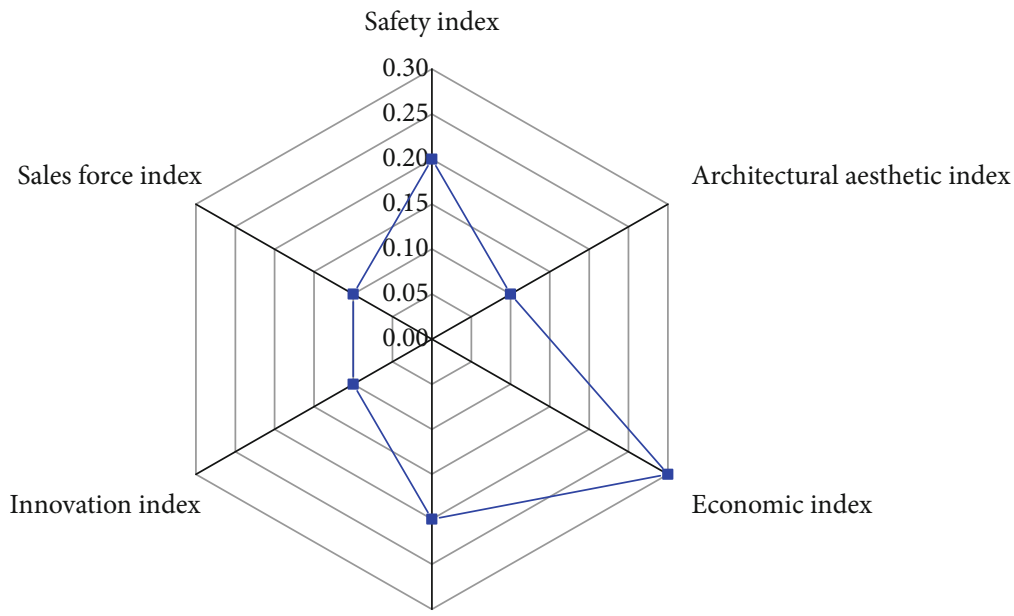

Energy-saving and environmental protection index

FIGURE 4: The key index weights of the product competency model.

TABLE 7: Competitive situation matrix of four products.

\begin{tabular}{|c|c|c|c|c|c|c|c|c|c|c|}
\hline \multirow[b]{2}{*}{ No. } & \multirow[b]{2}{*}{ Key competitive factors } & \multirow[b]{2}{*}{$\begin{array}{l}\text { Weight } \\
\text { factor }\end{array}$} & \multicolumn{2}{|c|}{ CIGS-BIPV } & \multicolumn{2}{|c|}{ Silica-based BIPV } & \multicolumn{2}{|c|}{ Glass curtain wall } & \multicolumn{2}{|c|}{ Exterior stone } \\
\hline & & & Score & $\begin{array}{l}\text { Weighted } \\
\text { value }\end{array}$ & Score & $\begin{array}{l}\text { Weighted } \\
\text { value }\end{array}$ & Score & $\begin{array}{l}\text { Weighted } \\
\text { value }\end{array}$ & Score & $\begin{array}{c}\text { Weighted } \\
\text { value }\end{array}$ \\
\hline 1 & Safety index & 0.20 & 90 & 18.00 & 88 & 17.60 & 95 & 19.00 & 85 & 17.00 \\
\hline 2 & Architectural aesthetic index & 0.10 & 90 & 9.00 & 88 & 8.80 & 95 & 9.50 & 90 & 9.00 \\
\hline 3 & Economic index & 0.30 & 75 & 22.50 & 80 & 24.00 & 85 & 25.50 & 90 & 27.00 \\
\hline 4 & $\begin{array}{l}\text { Energy-saving and environmental } \\
\text { protection index }\end{array}$ & 0.20 & 95 & 19.00 & 93 & 18.60 & 80 & 16.00 & 75 & 15.00 \\
\hline 5 & Innovation index & 0.10 & 95 & 9.50 & 92 & 9.20 & 80 & 8.00 & 75 & 7.50 \\
\hline 6 & Sales force index & 0.10 & 80 & 8.00 & 80 & 8.00 & 90 & 9.00 & 90 & 9.00 \\
\hline & & 1.00 & & 86.00 & & 86.20 & & 87.00 & & 84.50 \\
\hline
\end{tabular}

support for improvement and spread of sales force of CIGSBIPV, which has an annual production scale of $306 \mathrm{MW}$ in the first phase of the project.

Glass curtain wall and exterior stone have various sales channels with thorough manufacturer, middleman market, and retailer. Both CIGS-BIPV and silica-based BIPV are emerging, and they are at a disadvantage site in terms of the sales force competition in construction. Although the silica-based solar cell is mature in electricity generation, it lacks good large-scale demonstration and application in BIPV integration. Table 6 shows the competitiveness of sales force index for CIGS-BIPV, silica-based BIPV, glass curtain wall, and exterior stone. Although CIGS-BIPV products are supported by many powerful state-owned enterprises, foreign enterprises, and local enterprises, it is still necessary to build sales channels. In the early stage, financing and other ways should be used to increase capital investment in product production, especially the joint regulation and control of the state and the market, so as to promote the development of industrialization. As an emerging product, how to obtain customer satisfaction and recognition is of great importance for CIGS-BIPV. In addition to improving the innovation index and conversion efficiency of the product itself, market publicity also has to be taken good care of to promote products.

\section{Weight Analysis on the CIGS-BIPV Product Competency Model}

Through the comparison of six key strategic factors in the industry, the competitive advantages of CIGS-BIPV, silicabased BIPV, exterior stone, and glass curtain wall are analyzed. By analyzing the importance of successful operation of each factor in the industry, their weights are determined, from 0 (least important) to 1 (most important), and the sum of the weights is 1 . The weight can be acquired by the analytical hierarchy process (AHP) or expert discussion. The weights of safety index, building aesthetics index, economy index, energy conservation and environmental protection index, innovation index, and sales force index determined by expert discussion are $0.20,0.10,0.30,0.20$, 0.10 , and 0.10 , respectively, shown in Figure 4 . It is worth mention that these scores will change according to the location area, technological progress, policy regulations, etc. Relative ability strength of four products in each factor is evaluated, and the evaluation scores are $<60$ (weakest), 
60-70 (relatively weak), 70-80 (similar), 80-90 (relatively strong), and 90-100 (strongest). The products with the highest score in the key competitive factors represent the competitive advantage in this factor, and the score difference represents the relative competence.

Through the multiplication of evaluation value for each factor and the corresponding weight, weighted evaluation values of competitiveness for CIGS-BIPV, silica-based BIPV, glass curtain wall, and exterior stone are 86.00, 86.20, 87.00, and 84.50 , respectively. As shown in Table 7 , the glass curtain wall exhibits the strongest product competency in the comprehensive analysis of six indexes, followed by silica-based BIPV and CIGS-BIPV. It is important to point out that glass curtain wall and exterior stone are in the mature stage of lifecycle, while silica-based BIPV and CIGS-BIPV are both in the lead-in stage of lifecycle. It is expected that silica-based BIPV and CIGS-BIPV will develop substantially after 2025. Here, the calculation and analysis of silica-based BIPV and CIGS-BIPV are based on the technical and economic characteristics of the industry at its initial scale.

\section{Conclusions}

In this article, industry competition structure and competition situation are for the first time analyzed through "Porter's Five Forces Model." The index modeling approach is further adopted to quantitatively and qualitatively analyze the competency of CIGS-BIPV through six indexes: safety index, building aesthetics index, economic index, energy-saving and environmental protection index, innovation index, and sales force index. Besides, the weight analysis method is also performed for index modeling. This work indicates that in comparison with the glass curtain wall, exterior stone, and silica-based BIPV, CIGS-BIPV has an overall score of 86.00, with acceptable cost, beautiful appearance, high technology content, and strong product competitiveness. The electrical energy produced by CIGS-BIPV is a completely zero-emission, nonpolluting clean energy. People can use this clean energy to meet the needs of daily life, while reducing the negative impacts of environmental pollution and ecological damage caused by traditional coal-fired power generation. It is conducive to positively affecting China's adjustment of the energy industry structure and meeting the carbon emission reduction commitments of the international community as soon as possible.

\section{Data Availability}

The main data used to support the findings of this study are included within the article. Other data could also be available from the corresponding author upon request (Email address: Dr. Hui Kong: konghui@mail.tsinghua.edu.cn).

\section{Additional Points}

Highlights. (i) Using "Porter's Five Forces Model" to analyze the competitiveness of CIGS-BIPV products. (ii) Six indexes are chosen for the comparison of CIGS-BIPV, exterior stone, silica-based BIPV, etc. (iii) Competitive situation matrix of four building products are established and analyzed.

\section{Conflicts of Interest}

The authors declare that they have no known competing financial interests or personal relationships that could have appeared to influence the work reported in this paper.

\section{Acknowledgments}

This work was funded by the China Postdoctoral Science Foundation (No. 2019M660588), the Natural Science Foundation of China (No. 51906179), and the pilot programs for major science, technology, and innovation projects toward 2030 of China Energy Investment Corporation (No. GJNY2030XDXM-19-20.1). The authors gratefully acknowledge the National Research Foundation of Korea (NRF) grant funded by the Korea government (MSIT) (No. NRF2018M1A2A2063868 and No. NRF-2018R1C1B6006854). The authors also thank Teng Luo and Yinan Yang for valuable discussions.

\section{References}

[1] M. Theelen and F. Daume, "Stability of $\mathrm{Cu}(\mathrm{In}, \mathrm{Ga}) \mathrm{Se} 2$ solar cells: A literature review," Solar Energy, vol. 133, pp. 586627, 2016.

[2] J. Wang, H. Kong, Y. Xu, and J. Wu, "Experimental investigation of heat transfer and flow characteristics in finned copper foam heat sinks subjected to jet impingement cooling," Applied Energy, vol. 241, pp. 433-443, 2019.

[3] N. S. Lewis and D. G. Nocera, "Powering the planet: chemical challenges in solar energy utilization," Proceedings of the National Academy of Sciences of the United States of America, vol. 103, no. 43, pp. 15729-15735, 2006.

[4] H. Kong, Y. Hao, and H. Jin, "Isothermal versus twotemperature solar thermochemical fuel synthesis: a comparative study," Applied Energy, vol. 228, pp. 301-308, 2018.

[5] B. Wang, H. Kong, H. Wang, Y. Wang, and X. Hu, "Kinetic and thermodynamic analyses of mid/low-temperature ammonia decomposition in solar-driven hydrogen permeation membrane reactor," International Journal of Hydrogen Energy, vol. 44, no. 49, pp. 26874-26887, 2019.

[6] H. Kong, X. Kong, H. Wang, and J. Wang, "A strategy for optimizing efficiencies of solar thermochemical fuel production based on nonstoichiometric oxides," International Journal of Hydrogen Energy, vol. 44, no. 36, pp. 19585-19594, 2019.

[7] H. Wang, H. Kong, Z. Pu, Y. Li, and X. Hu, "Feasibility of high efficient solar hydrogen generation system integrating photovoltaic cell/photon-enhanced thermionic emission and hightemperature electrolysis cell," Energy Conversion and Management, vol. 210, p. 112699, 2020.

[8] S. U. M. Khan, "Efficient photochemical water splitting by a chemically modified n- $\mathrm{TiO}_{2}$," Science, vol. 297, no. 5590, pp. 2243-2245, 2002.

[9] H. Wang, Y. Hao, and H. Kong, "Thermodynamic study on solar thermochemical fuel production with oxygen permeation membrane reactors," International Journal of Energy Research, vol. 39, no. 13, pp. 1790-1799, 2015. 
[10] H. Wang, M. Liu, H. Kong, and Y. Hao, “Thermodynamic analysis on mid/low temperature solar methane steam reforming with hydrogen permeation membrane reactors," Applied Thermal Engineering, vol. 152, pp. 925-936, 2019.

[11] https://www.iea.org/renewables2019/.

[12] H. Kong, Y. Hao, and H. Wang, "A solar thermochemical fuel production system integrated with fossil fuel heat recuperation," Applied Thermal Engineering, vol. 108, pp. 958-966, 2016.

[13] H. Kong, X. Kong, J. Wang, and J. Zhang, “Thermodynamic analysis of a solar thermochemical cycle-based direct coal liquefaction system for oil production," Energy, vol. 179, pp. 1279-1287, 2019.

[14] http://fjb.nea.gov.cn/news_view.aspx?id=27538.

[15] I. Visa, B. Burduhos, M. Neagoe, M. Moldovan, and A. Duta, "Comparative analysis of the infield response of five types of photovoltaic modules," Renewable Energy, vol. 95, pp. 178190, 2016.

[16] L. Yin, Y. Jiang, and R. Qiu, "Combustion behaviors of cigs thin-film solar modules from cone calorimeter tests," Materials, vol. 11, no. 8, p. 1353, 2018.

[17] V. S. Saji, I. H. Choi, and C. W. Lee, "Progress in electrodeposited absorber layer for $\mathrm{CuIn}_{(1-\mathrm{x})} \mathrm{Ga}_{\mathrm{x}} \mathrm{Se}_{2}$ (CIGS) solar cells," Solar Energy, vol. 85, no. 11, pp. 2666-2678, 2011.

[18] J. Ramanujam, D. M. Bishop, T. K. Todorov et al., "Flexible CIGS, CdTe and a-Si:H based thin film solar cells: a review," Progress in Materials Science, vol. 110, p. 100619, 2020.

[19] A. Fakharuddin, R. Jose, T. M. Brown, F. Fabregat-Santiago, and J. Bisquert, "A perspective on the production of dyesensitized solar modules," Energy \& Environmental Science, vol. 7, no. 12, pp. 3952-3981, 2014.

[20] M. E. Porter, "Competitive strategy," Measuring Business Excellence, vol. 1, no. 2, pp. 12-17, 1997.

[21] M. E. Porter, "The five competitive forces that shape strategy," Harvard Business Review, vol. 86, no. 1, pp. 78-93, 137, 2008.

[22] W. Yunna and Y. Yisheng, "The competition situation analysis of shale gas industry in China: applying Porter's five forces and scenario model," Renewable \& Sustainable Energy Reviews, vol. 40, pp. 798-805, 2014.

[23] Z. Y. Zhao, J. Zuo, P. H. Wu, H. Yan, and G. Zillante, "Competitiveness assessment of the biomass power generation industry in China: a five forces model study," Renewable Energy, vol. 89, pp. 144-153, 2016.

[24] M. Mahat, "The competitive forces that shape Australian medical education," International Journal of Educational Management, vol. 33, no. 5, pp. 1082-1093, 2019.

[25] C. M. Koo, C. E. Koh, and K. Nam, "An examination of Porter's competitive strategies in electronic virtual markets: a comparison of two on-line business models," International Journal of Electronic Commerce, vol. 9, no. 1, pp. 163-180, 2014.

[26] G. D. Karagiannopoulos, N. Georgopoulos, and K. Nikolopoulos, "Fathoming Porter's five forces model in the internet era," Info, vol. 7, no. 6, pp. 66-76, 2005.

[27] http://www.mohurd.gov.cn/wjfb/201908/t20190802_241327 .html.

[28] J. Chantana, S. Hirai, M. Inoue, T. Masuda, and T. Minemoto, "Flexible $\mathrm{Cu}(\mathrm{In}, \mathrm{Ga}) \mathrm{Se}_{2}$ solar cell with superstrate-type configuration fabricated by a lift-off process," Thin Solid Films, vol. 662, pp. 110-115, 2018.

[29] http://guangfu.bjx.com.cn/news/20200103/1033449.shtml.
[30] http://guangfu.bjx.com.cn/news/20191125/1023147.shtml.

[31] P. K. Ng and N. Mithraratne, "Lifetime performance of semitransparent building-integrated photovoltaic (BIPV) glazing systems in the tropics," Renewable \& Sustainable Energy Reviews, vol. 31, pp. 736-745, 2014.

[32] http://www.ndrc.gov.cn/gzdt/201904/t20190430_935315 .html.

[33] P. K. Mishra, V. Dave, R. Chandra, J. N. Prasad, and A. K. Choudhary, "Effect of processing parameter on structural, optical and electrical properties of photovoltaic chalcogenide nanostructured RF magnetron sputtered thin absorbing films," Materials Science in Semiconductor Processing, vol. 25, pp. 307-319, 2014.

[34] https://www.nrel.gov/pv/cell-efficiency.html.

[35] P. Jackson, D. Hariskos, R. Wuerz et al., "Properties of $\mathrm{Cu}(\mathrm{In}$,Ga)Se2solar cells with new record efficiencies up to $21.7 \%$," Physica Status Solidi-Rapid Research Letters, vol. 9, no. 1, pp. 28-31, 2015.

[36] R. H. French, J. M. Rodríguez-Parada, M. K. Yang, R. A. Derryberry, and N. T. Pfeiffenberger, "Optical properties of polymeric materials for concentrator photovoltaic systems," Solar Energy Materials and Solar Cells, vol. 95, no. 8, pp. 2077-2086, 2011.

[37] D. Rudmann, G. Bilger, M. Kaelin, F.-J. Haug, H. Zogg, and A. N. Tiwari, "Effects of NaF coevaporation on structural properties of $\mathrm{Cu}(\mathrm{In}, \mathrm{Ga}) \mathrm{Se}_{2}$ thin films," Thin Solid Films, vol. 431-432, pp. 37-40, 2003. 